\title{
STUDIES ON THE MICROSTRUCTURE OF EPOXY-CEMENT COMPOSITES
}

\section{P. LUKOWSKI ${ }^{1}$}

\begin{abstract}
Introduction of polymers into the cement composites improves some of the properties of concretes and mortars. Therefore, the polymer-cement composites are successfully used in construction. The model of microstructure formation in cement composites modified with thermoplastic polymer (pre-mix modifiers) has already been developed and successfully implemented. However, the formation of microstructure in the case of epoxy-cement composites (containing post-mix modifier) demonstrates some peculiarities which should be taken into account when modelling the process. The microstructure of epoxy-cement composites and its formation is discussed in the paper. The model is offered, formulated on the basis of the microscopic observations and results of testing.
\end{abstract}

Keywords: cement, epoxy, polymer, composite, modification, microstructure

\section{INTRODUCTION}

Progress in building materials engineering is today being done by material modification [1]. Not only the materials intended for use in extreme conditions, like underwater concrete [2] or reactive powders concrete [3], but also the materials considered "traditional", such as earth [4, 5] or ceramics [6], are improved this way. Concrete is particularly predestined for material modification, due to the possibility to easily manipulate its composition. Additions and admixtures are inherent components of the modern concrete, as defined by the European Standard EN 206 "Concrete Specification, performance, production and conformity". The mineral [7, 8] and organic [9] modifiers are employed, also on the nanometric level [10].

\footnotetext{
${ }^{1}$ Prof., DSc., PhD., Eng., Warsaw University of Technology, Faculty of Civil Engineering, Al. Armii Ludowej 16, 00637 Warsaw, Poland, e-mail: p.lukowski@il.pw.edu.pl
} 
One of the possibilities of modification is introduction of polymer into concrete as a co-binder. This creates an additional heterogeneity of the composite, conducive to changing its performance in various ways [11]. The polymer-cement concretes (PCC) demonstrate substantial advantages over the ordinary concrete regarding to such properties as tensile and flexural strength, adhesion to various substrates, tightness and resistance to some chemical attacks [12]. This leads to the growing use of polymer-cement composites in repair and protection of the concrete structures, making pavements, including industrial floors, and production of the pre-cast elements [12, 13, 14].

The polymer-cement composites themselves have also undergone to modification, for example by introduction of the mineral powders [15]. The scientific basis for the improvement of PCC performance are similar to those for the other composites. On the one hand, the statistical methods of optimization are developed, the same way as it is observed in theory of structures and managing $[16,17]$; the advanced methods are employed, like using the artificial neural networks or fuzzy logic [18]. On the other hand, the efficient modification is possible if reliable model of the microstructure formation is available, including such questions as interaction between polymer and cement and creation of continuous polymer film [19].

The appropriate model for PCC has been first proposed by Ohama [20] and then developed into the integrated, comprehensive model by Beeldens et al. [21], who paid attention to the positioning of the mechanisms on the time scale and to the interaction between the different components. However, the aforementioned model is focused on the formation of polymer film by coalescence of the polymer particles; this means that it is fully applicable for the pre-mix (chemically inactive, thermoplastic) polymer modifiers, like polyacrylates (polyacrylic esters), styrene-butadiene rubber, styrene-acrylic co-polymers, ethylene-vinyl acetate co-polymers, etc. If the post-mix modifier is applied (usually epoxy resin), the chemical reaction between the resin and the hardener takes place, leading to spatial crosslinking of the polymer. This creates more complicated system, as the additional factor has to be taken into account. In this paper, the model of microstructure formation of PCC in the case of epoxy modifier is offered.

\section{EXPERIMENTAL}

First, the images of the microstructure of epoxy-cement mortar have been obtained using highresolution scanning microscope HITACHI 5500. Then, the mechanical properties of PCC were investigated to verify the observations.

The materials used for preparing the polymer-cement mortars were: 
- Portland cement CEM I 32.5 according to EN 197-1 "Cement - Part 1: Composition, specifications and conformity criteria for common cements",

- CEN standard sand 0/2 mm according to EN 196-1 "Methods of testing cement - Part 1: Determination of strength",

- commercially available polymer modifiers: solvent free, low-viscosity epoxy resin with amine hardener and polyacrylic esters dispersion.

The reference material was unmodified Portland cement mortar according to EN 196-1 (cement to sand ratio equal to 0.33 and water to cement ratio equal to 0.5 ). Polymer to cement ratio in the polymer modified mortars was 0.05 to 0.30 . The selected properties of polymer-cement mortars were determined after 28 days of mixed-regime curing: the specimens were tightly covered with plastic sheet for 1 day, demoulded, immersed in water at the temperature $20-22^{\circ} \mathrm{C}$ for 5 days and then stored in laboratory air-dry environment (temperature $20-22^{\circ} \mathrm{C}$ and relative humidity $60 \pm 5 \%$ ).

The tests of flexural and compressive strength of the mortars were conducted using the prism specimens with dimensions 16x16x4 cm, prepared according to EN 196-1. For tensile strength testing, the "eight-shaped" specimens of the mortars were prepared according to the Polish Standard PN-B-04500 "Mortars - Testing of mechanical properties".

Flexural and tensile strength of the mortars were determined according to PN-B-04500, while compressive strength was determined according to EN 12190 "Products and systems for the protection and repair of concrete structures - Test methods - Determination of compressive strength of repair mortar". Computer controlled INSTRON testing machine was used.

\section{RESULTS AND DISCUSSION}

\subsection{MORTARS MODIFIED WITH EPOXY RESIN AND POLYACRYLIC ESTERS DISPERSION}

Epoxy resin, due to the chemical reaction with the hardener, forms the spatial cross-linked structure. However, the polymer film created inside the cement matrix is more heterogeneous, as compared to that created by the polyacrylic modifier, particularly when the polymer content is low; the lumps and discontinuous fragments of the hardened resin can be observed (Fig. 1). At this level of the polymer content, polyacrylic ester is expected to give better results of modification than epoxy resin. With increasing amount of the epoxy modifier, the structure of the hardened resin becomes more homogeneous (Fig. 2). In this situation, the better mechanical properties of the hardened epoxy resin should reverse the situation in favor of the epoxy-cement composite. 

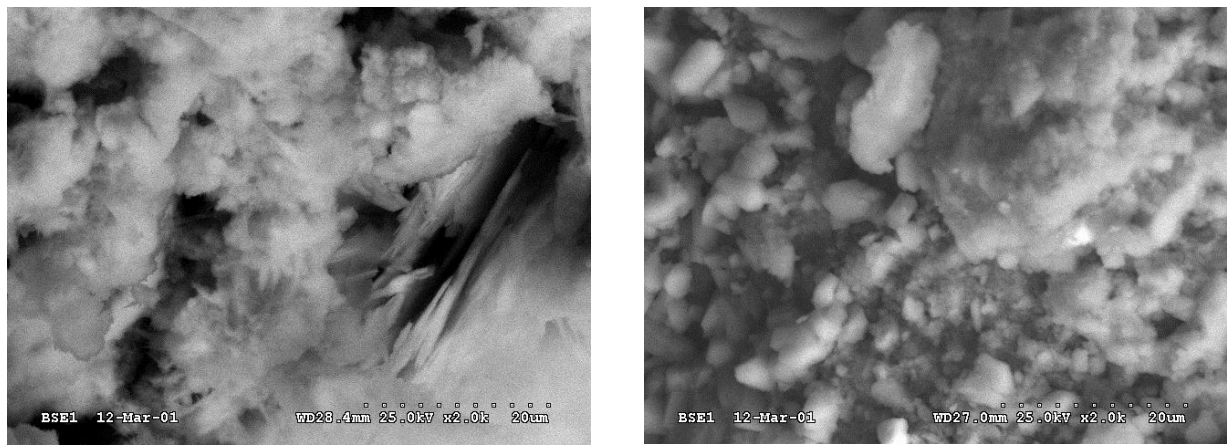

Fig. 1. SEM image of microstructure of cement composite modified with: polyacrylic esters dispersion (left), epoxy resin (right); polymer to cement ratio $=0.10$
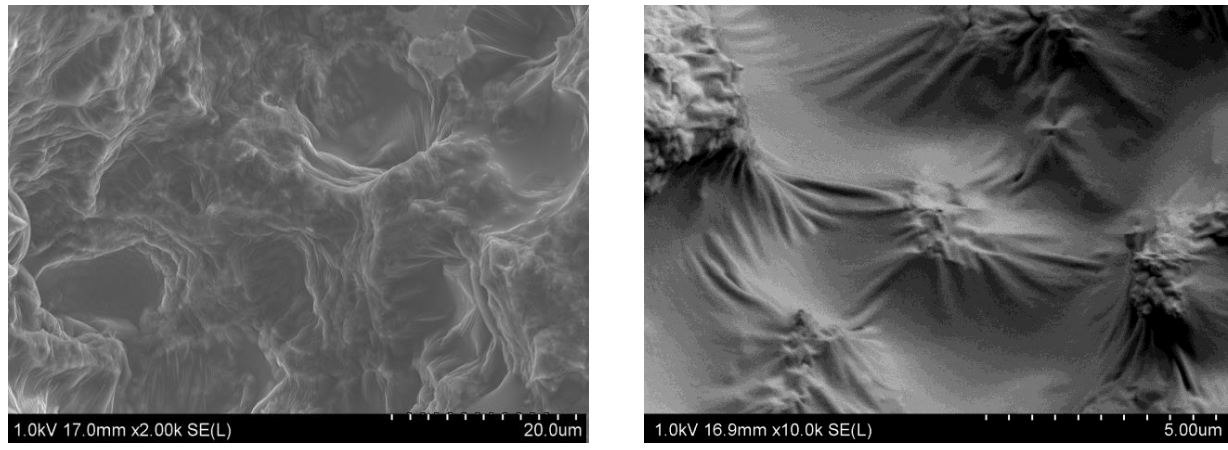

Fig. 2. SEM image of microstructure of cement composite modified with epoxy resin; polymer to cement ratio $=0.20$

The results of testing of tensile strength (Fig. 3), flexural strength (Fig. 4) and compressive strength (Fig. 5) confirm the expectations based on the microscopic observations. Both epoxy resin and polyacrylic ester have a positive effect on the composite, however, the results show that polyacrylic ester are more effective than epoxy resin when used in relatively lower amounts. When the content of the polymer increases, the epoxy resin becomes more efficient.

For estimation of the polymer content, at which the composite containing epoxy resin gains an advantage over that modified with polyacrylic ester, the model relationships properties - polymer content were calulated on the basis of the tests results, in the form of $2^{\text {nd }}$ and $3^{\text {rd }}$ degree polynomials (Table 1). The determination coefficients $\mathrm{R}^{2}$ were in every case at the very high level 0.99 . 


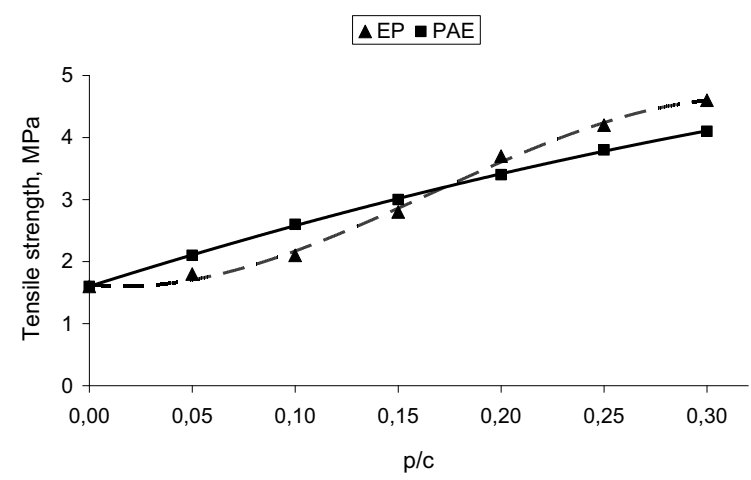

Fig. 3. Tensile strength of polymer-cement mortars with epoxy resin (EP) and polyacrylic esters (PAE)

\section{$\triangle \mathrm{EP} \square \mathrm{PAE}$}

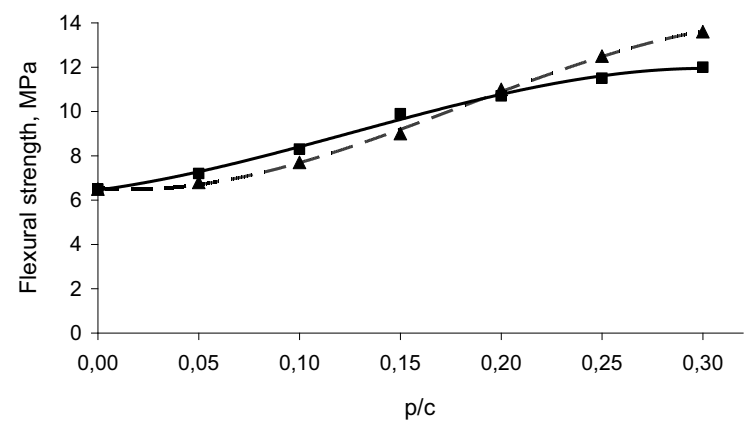

Fig. 4. Flexural strength of polymer-cement mortars with epoxy resin (EP) and polyacrylic esters (PAE)

\section{$\triangle \mathrm{EP} \square \mathrm{PAE}$}

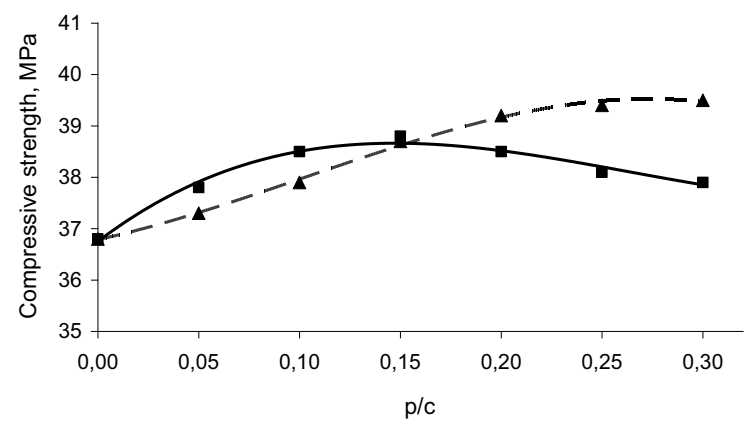

Fig. 5. Compressive strength of polymer-cement mortars with epoxy resin (EP) and polyacrylic esters (PAE) 
Table 1. Relationships between the determined properties and polymer content $(\mathrm{p} / \mathrm{c})$

\begin{tabular}{|c|c|c|c|}
\hline \multirow[b]{2}{*}{ Property } & \multicolumn{2}{|c|}{ Polymer modifier } & \multirow{2}{*}{$\begin{array}{l}\text { Polymer content, at which } \\
\text { values for EP begin to } \\
\text { exceed those for PAE }\end{array}$} \\
\hline & epoxy resin (EP) & polyacrylic ester (PAE) & \\
\hline $\begin{array}{l}\text { Tensile } \\
\text { strength }\end{array}$ & $\begin{array}{c}\mathrm{f}_{\mathrm{t}}=-222.22(\mathrm{p} / \mathrm{c})^{3}+111.43(\mathrm{p} / \mathrm{c})^{2} \\
-3.54(\mathrm{p} / \mathrm{c})+1.63\end{array}$ & $\begin{array}{c}\mathrm{f}_{\mathrm{t}}=-7.14(\mathrm{p} / \mathrm{c})^{2}+10.50(\mathrm{p} / \mathrm{c}) \\
+1.60\end{array}$ & $\mathrm{p} / \mathrm{c}=0.17$ \\
\hline $\begin{array}{l}\text { Flexural } \\
\text { strength }\end{array}$ & $\begin{array}{c}\mathrm{f}_{\mathrm{b}}=-422.22(\mathrm{p} / \mathrm{c})^{3}+230.00(\mathrm{p} / \mathrm{c})^{2}- \\
7.40(\mathrm{p} / \mathrm{c})+6.55\end{array}$ & $\begin{array}{c}\mathrm{f}_{\mathrm{b}}=-266.67(\mathrm{p} / \mathrm{c})^{3}+100.48(\mathrm{p} / \mathrm{c})^{2}+ \\
12.17(\mathrm{p} / \mathrm{c})+6.45\end{array}$ & $\mathrm{p} / \mathrm{c}=0.19$ \\
\hline $\begin{array}{l}\text { Compressive } \\
\text { strength }\end{array}$ & $\begin{aligned} \mathrm{f}_{\mathrm{c}}= & -155.56(\mathrm{p} / \mathrm{c})^{3}+48.09(\mathrm{p} / \mathrm{c})^{2} \\
& +8.51(\mathrm{p} / \mathrm{c})+36.796\end{aligned}$ & $\begin{aligned} \mathrm{f}_{\mathrm{c}}= & 177.78(\mathrm{p} / \mathrm{c})^{3}-140.48(\mathrm{p} / \mathrm{c})^{2} \\
& +29.82(\mathrm{p} / \mathrm{c})+36.75\end{aligned}$ & $\mathrm{p} / \mathrm{c}=0.15$ \\
\hline
\end{tabular}

As it is seen, the epoxy resin is more efficient modifier when the polymer content is higher than 15 $20 \%$ of the cement mass. This is in good agreement with the microscopic observations.

\subsection{EPOXY-CEMENT MORTARS WITH AND WITHOUT HARDENER}

Conventional epoxy modifier is two-component system, consisting of the resin and the hardener. However, epoxy resin can also harden by catalytic action of alkaline environment without the hardener. Ohama and his co-workers have first proposed and demonstrated that this process can proceed inside the cement paste [22], allowing for some specific features of epoxy-cement composites, like ability to partial self-repairing [23].

When the epoxy resin is applied to the cement mortar without a hardener, the more continuous polymer film is formed (Fig. 6). Same observation was reported by Jo [24].
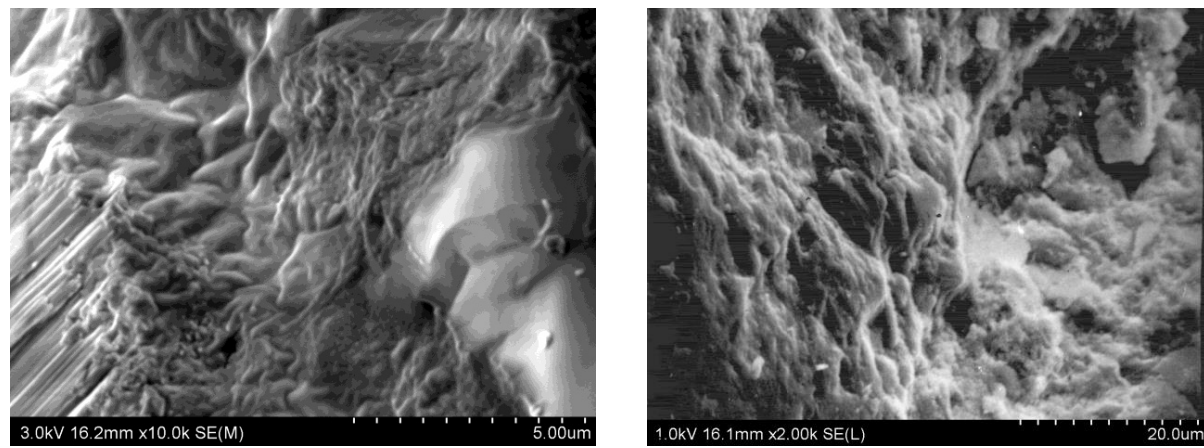

Fig. 6. SEM image of microstructure of cement composite modified using epoxy resin without a hardener; polymer to cement ratio $=0.15$ 
Tests were carried out for comparing the flexural and compressive strength of epoxy-cement mortars with and without hardener at various content of polymer (Figs. 7 and 8). The results show that the epoxy resin without a hardener can be more efficient at low content, while at the higher contents of the modifier the presence of the hardener gives better results. This can be explained by the favorable, more homogenous structure of the catalytically hardened resin. When the content of the resin increases, part of it remains unhardened and make the composite performance worse.

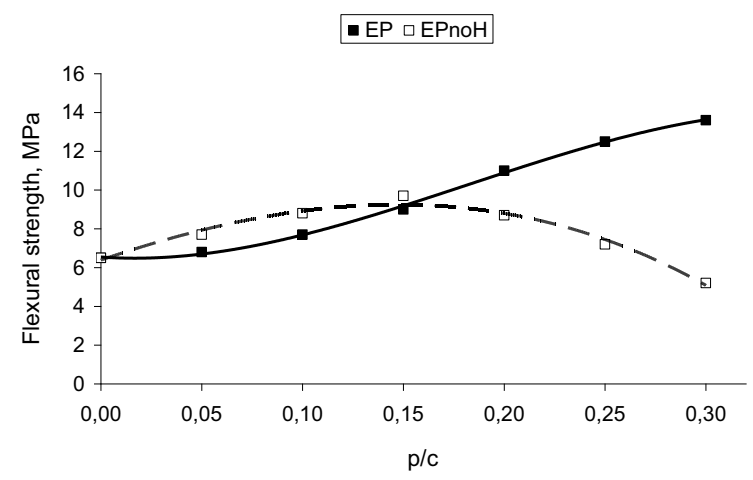

Fig. 7. Flexural strength of epoxy-cement mortars with hardener (EP) and without hardener (EPnoH)

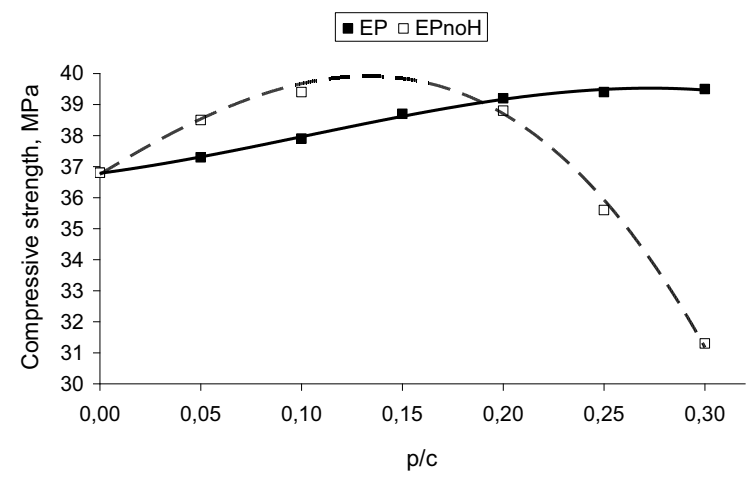

Fig. 8. Compressive strength of epoxy-cement mortars with hardener (EP) and without hardener (EPnoH)

For estimation of the polymer content, at which the composite containing epoxy resin with a hardener begins to have better mechanical properties than that without a hardener, the model relationships properties - polymer content were calulated on the basis of the tests results (Table 2). The determination coefficients $\mathrm{R}^{2}$ were in every case at the very high level 0.99 . 
Table 2. Relationships between the determined properties and epoxy resin polymer content $(\mathrm{p} / \mathrm{c})$

\begin{tabular}{|c|c|c|c|}
\hline \multirow{2}{*}{ Property } & \multicolumn{2}{|c|}{ Polymer modifier } & $\begin{array}{c}\text { Polymer content, at which } \\
\text { values for EP begin to } \\
\text { exceed those for EPnoH }\end{array}$ \\
\cline { 2 - 4 } & epoxy resin with a hardener $(\mathrm{EP})$ & $\begin{array}{c}\text { epoxy resin without a hardener } \\
(\mathrm{EPnoH})\end{array}$ & $\mathrm{p} / \mathrm{c}=0.15$ \\
\hline $\begin{array}{c}\text { Flexural } \\
\text { strength }\end{array}$ & $\begin{array}{c}\mathrm{f}_{\mathrm{b}}=-422.22(\mathrm{p} / \mathrm{c})^{3}+230.00(\mathrm{p} / \mathrm{c})^{2} \\
-7.40(\mathrm{p} / \mathrm{c})+6.55\end{array}$ & $\begin{array}{c}\mathrm{f}_{\mathrm{b}}=-155.56(\mathrm{p} / \mathrm{c})^{3}-86.19(\mathrm{p} / \mathrm{c})^{2} \\
+35.51(\mathrm{p} / \mathrm{c})+6.39\end{array}$ & $\mathrm{p} / \mathrm{c}=0.19$ \\
\hline $\begin{array}{c}\text { Compressive } \\
\text { strength }\end{array}$ & $\begin{array}{c}\mathrm{f}_{\mathrm{c}}=-155.56(\mathrm{p} / \mathrm{c})^{3}+48.09(\mathrm{p} / \mathrm{c})^{2} \\
+8.51(\mathrm{p} / \mathrm{c})+36.79\end{array}$ & $\begin{array}{c}\mathrm{f}_{\mathrm{c}}=-444.44(\mathrm{p} / \mathrm{c})^{3}-61.43(\mathrm{p} / \mathrm{c})^{2} \\
+39.85(\mathrm{p} / \mathrm{c})+36.75\end{array}$ & \begin{tabular}{c} 
\\
\hline
\end{tabular} \\
\hline
\end{tabular}

As it is seen, the epoxy resin without a hardener is more efficient in modification of the composite when the polymer content does not exceed $15-20 \%$ of the cement mass. This is in general agreement with Jo [24] and Ohama [25] findings, who recommend for such system the p/c ratio not higher than 0.20 .

\section{MODEL OF MICROSTRUCTURE FORMATION}

On the base of the presented test results and SEM observations, the mechanism of formation of the microstructure in epoxy-cement composites is offered. The model is to some extent similar to that established for the pre-mix modifiers, however, some significant peculiarities need to be taken into account. In the case of PCC with thermoplastic polymers, the main processes involved are the cement hydration and the polymer film formation on the way of coalescence of dispersed polymer particles [26]. When the epoxy resin is used as a modifier, the additional process takes places, namely the chemical reaction of the resin with the hardener, leading to cross-linking of the resin.

The epoxy resin creates an emulsion - a suspension of microdroplets - with the mixing water. The Portland cement starts to hydrate and simultaneously the resin, within the separated microdroplets, begins to harden by the reaction with the hardener. If the content of polymer is low, the coalescence of the resin microdroplets cannot start effectively, because it is possible at some level of polymer concentration in the liquid phase, usually defined as $60-70 \%$ by volume [27]. The water is gradually removed from the system as the hydration progresses and the material dries, however, when the suitable concentration of polymer is achieved, the resin inside the microdroplets is already mostly hardened and the coalescence is again unlike. As a result, the structure of the hardened epoxy resin is heterogeneous and consists rather of the separated lumps then continuous polymer film.

The situation changes when the content of the epoxy resin increases; the epoxy modifier is then more effective than the polyacrylic esters. This can be attributed not only to the bigger contribution of the epoxy resin properties, but also to the increasing possibility of the coalescence, since the 
sufficient level of polymer concentration is achieved earlier. Thus, more homogeneous and continuous polymer film can be formed.

Interesting conclusions can be drawn from the analysis of the results of modifying of the composite with the epoxy resin without hardener. The cross-linking of the resin due to the catalytic action of environment is slow; the hardening of the resin inside the microdroplets is delayed and the possibility of coalescence increases. In consequence, the more homogeneous, continuous polymer film can be formed and the final strength of the composite is higher than in the case of epoxy resin with the hardener. The mechanism of microstructure formation is, therefore, more like that proposed for the thermoplastic polymers. However, when the content of the epoxy resin increases, the excess of unhardened resin worsens the composite properties.

\section{SUMMARY}

The reliable model of microstructure formation is one of the crucial elements of understanding the nature of the composite and its proper application. Such integrated model has been successfully developed for the polymer-cement composites with thermoplastic polymers. However, in the case of epoxy-cement composites, the process is not fully explained yet. In this paper, the respective mechanism has been discussed and the explanation of the observed phenomena has been offered.

The proposed mechanism of microstructure formation in the epoxy-cement composites was presented on the basis of the results of testing and microscopic observations. However, there is need for the further investigations and discussions.

\section{REFERENCES}

1. P. Łukowski, "Material modification of concrete" (in Polish), SPC - Polski Cement, Cracow, 2016.

2. E. Horszczaruk, P. Brzozowski, "Bond strength of underwater repair concretes under hydrostatic pressure", Construction and Building Materials, 72: 167-173, 2014.

3. T. Zdeb, J. Śliwiński, ,The influence of selected material and technological factors on mechanical properties and microstructure of reactive powder concrete (RPC)", Archives of Civil Engineering, LVII, 2: 227-246, 2011.

4. P. Narloch, P. Woyciechowski, P. Jęda, "The influence of loam type and cement content on the compressive strength of rammed earth”, Archives of Civil Engineering, LXI, 1: 73-88, 2015.

5. P. Narloch, P. Woyciechowski, E. Dmowska, K. Halemba, „Durability assessment of monolithic rammed earth walls", Archives of Civil Engineering, LXI, 2: 73-88, 2015.

6. T. Stryszewska, "The change in selected properties of ceramic materials obtained from ceramic brick treated by the sulphate and chloride ions", Construction and Building Materials, 66: 268-274, 2014.

7. K. Malhotra, "High-performance, high-volume fly ash concrete", Concrete International, 24: 30-34, 2002.

8. P. Lukowski, A. Salih, "Durability of mortars containing ground granulated blast-furnace slag in acid and sulphate environment", $7^{\text {th }}$ Scientific-Technical Conference "Material Problems in Civil Engineering (MATBUD’2015)”, Cracow, Poland, 2015, Procedia Engineering, 108: 47-54, 2015. 
9. D. Van Gemert, L. Czarnecki, M. Maultzsch, H. Schorn, A. Beeldens, P. Łukowski, E. Knapen, “Cement concrete and concrete-polymer composites: Two merging worlds", Cement and Concrete Composites 27: 926933, 2005.

10. P. Sikora, P. Łukowski, K. Cendrowski, E. Horszczaruk, E. Mijowska, „The effect of nanosilica on the mechanical properties of polymer-cement composites (PCC)", $7^{\text {th }}$ Scientific-Technical Conference "Material Problems in Civil Engineering (MATBUD’2015)", Cracow, Poland, 2015, Procedia Engineering, 108: 139145, 2015.

11. L. Czarnecki, P. Łukowski, R. Nejman, "The statistical evaluation of epoxy concrete heterogeneity", Cement and Concrete Composites, 18: 417-428, 1996.

12. L. Czarnecki, P. Łukowski, "Polymer-cement concretes", Cement Wapno Beton 5: 243-258, 2010.

13. L. Czarnecki, P. Lukowski, „An usability approach to technical evaluation of the polymer coatings for concrete substrate: $2^{\text {nd }}$ International RILEM Symposium on Adhesion between Polymers and Concrete, Dresden, Germany, 1999, RILEM Proceedings, 9: 173-180, 1999.

14. B. Chmielewska, "Adhesion strength and other mechanical properties of SBR modified concrete", International Journal of Concrete Structures and Materials, 2: 3-8, 2008.

15. B. Jaworska, J. Sokołowska, P. Łukowski, J. Jaworski, „Waste mineral powders as a components of polymercement composites", Archives of Civil Engineering, LXI, 4: 199-210, 2015.

16. M. Książek, P. Nowak, S. Kivrak, J. Rosłon, L. Ustinovichius, "Computer-aided decision-making in construction project development”, Journal of Civil Engineering and Management, 21: 248-259, 2015.

17. M. Książek, P. Nowak, J. Rosłon, T. Wieczorek, "Multicriteria assessment of selected solutions for the building structural walls", $23^{\text {rd }}$ Russian-Polish-Slovak Seminar on Theoretical Foundation of Civil Engineering TFoCE'2014, Wrocław-Szklarska Poręba; Poland; Procedia Engineering, 91: 406-411, 2014.

18. N. Ibadov, "Fuzzy estimation of activities duration in construction projects", Archives of Civil Engineering, LXI, 2: 23-34, 2015.

19. P. Łukowski, "Continuity threshold of the polymer phase in polymer-cement composites", Archives of Civil Engineering, 3: 559-571, 2008.

20. Y. Ohama, "Handbook of polymer-modified concrete and mortars, properties and process technology", Park Ridge, New Jersey, Noyes Publications, 1995.

21. A. Beeldens, D. Van Gemert, H. Schorn, Y. Ohama, L. Czarnecki, "From microstructure to macrostructure: an integrated model of structure formation in polymer modified concrete", RILEM International Journal Materials and Structures 280: 601-607, 2005.

22. Y. Ohama, K. Demura, T. Endo, "Properties of polymer-modified mortars using epoxy resin without hardener", Polymer-Modified Hydraulic-Cement Mixtures. Special Technical Publication ASTM-STP 1176, Philadelphia, USA, 90-103, 1993.

23. P. Łukowski, G. Adamczewski, "Self-repairing of polymer-cement concrete", Bulletin of the Polish Academy of Sciences - Technical Sciences, 61: 195-200, 2013.

24. Y. Jo, "Basic properties of epoxy cement mortars without hardener after outdoor exposure", Construction and Building Materials 22: 911-920, 2008.

25. Y. Ohama, "Polymer-based admixtures", Cement and Concrete Composites 20: 189-212, 1998.

26. M. Afridi, Y. Ohama, K. Demura, M. Iqbal, "Development of polymer films by the coalescence of polymer particles in powdered and aqueous polymer-modified mortars", Cement and Concrete Research 33: 1715-1721, 2003.

27. N. Pramojaney, G. Poehlein, J. Vanderhoff, „A mathematical model for the drying of latex films”, Drying 2: 93-100, 1980.

Received 31.03. 2016

Revised 18.05. 2016

\section{ACKNOWLEDGEMENT}

The paper was prepared with the financial support by Faculty of Civil Engineering, Warsaw University of Technology. 


\section{LIST OF FIGURES AND TABLES:}

Fig. 1. SEM image of microstructure of cement composite modified with: polyacrylic esters dispersion (left), epoxy resin (right); polymer to cement ratio $=0.10$

Rys. 1. Obraz SEM mikrostruktury kompozytu cementowego modyfikowanego: dyspersją poliestrów akrylowych (po lewej), żywicą epoksydową (po prawej); proporcja polimeru do cementu $=0,10$

Fig. 2. SEM image of microstructure of cement composite modified with epoxy resin; polymer to cement ratio $=0.20$

Rys. 2. Obraz SEM mikrostruktury kompozytu cementowego modyfikowanego żywicą epoksydową; proporcja polimeru do cementu $=0,20$

Fig. 3. Tensile strength of polymer-cement mortars with epoxy resin (EP) and polyacrylic esters (PAE)

Rys. 3. Wytrzymałość na rozciąganie zapraw polimerowo-cementowych zawierających żywicę epoksydową (EP) oraz poliestry akrylowe (PAE)

Fig. 4. Flexural strength of polymer-cement mortars with epoxy resin (EP) and polyacrylic esters (PAE) Rys. 4. Wytrzymałość na zginanie zapraw polimerowo-cementowych zawierających żywicę epoksydową (EP) oraz poliestry akrylowe (PAE)

Fig. 5. Compressive strength of polymer-cement mortars with epoxy resin (EP) and polyacrylic esters (PAE) Rys. 5. Wytrzymałość na ściskanie zapraw polimerowo-cementowych zawierających żywicę epoksydową (EP) oraz poliestry akrylowe (PAE)

Fig. 6. SEM image of microstructure of the cement composite modified using epoxy resin without a hardener; polymer to cement ratio $=0.15$

Rys. 6. Obraz SEM mikrostruktury kompozytu cementowego modyfikowanego żywicą epoksydową bez utwardzacza; proporcja polimeru do cementu $=0,15$

Fig. 7. Flexural strength of epoxy-cement mortars with hardener (EP) and without hardener (EPnoH) Rys. 7. Wytrzymałość na zginanie zapraw epoksydowo-cementowych z utwardzaczem (EP) i bez utwardzacza (EPnoH)

Fig. 8. Compressive strength of epoxy-cement mortars with hardener (EP) and without hardener (EPnoH) Rys. 8. Wytrzymałość na ściskanie zapraw epoksydowo-cementowych z utwardzaczem (EP) i bez utwardzacza (EPnoH)

Table 1. Relationships between the determined properties and polymer content (p/c)

Tablica 1. Zależności między oznaczanymi właściwościami a zawartością polimeru (p/c)

Table 2. Relationships between the determined properties and epoxy resin polymer content (p/c)

Tablica 2. Zależności między oznaczanymi właściwościami a zawartością żywicy epoksydowej (p/c) 


\section{BADANIA NAD MIKROSTRUKTURĄ KOMPOZYTÓW EPOKSYDOWO-CEMENTOWYCH}

Slowa kluczowe: cement, kompozyt, mikrostruktura, modyfikacja, polimer, żywica epoksydowa

\section{STRESZCZENIE:}

Betony i zaprawy polimerowo-cementowe (Polymer-Cement Composites, PCC), otrzymywane przez dodanie polimeru do mieszanki betonowej lub mieszanki zaprawy, przewyższają zwykły beton wytrzymałością na zginanie i rozciąganie, przyczepnością do różnych podłoży, w tym betonu, oraz szczelnością względem cieczy i gazów. PCC są szeroko stosowane w budownictwie; szczególny obszar ich użytkowania stanowią naprawy i ochrona konstrukcji betonowych, wykonywanie nawierzchni oraz wytwarzanie elementów prefabrykowanych.

Wiązanie i twardnienie kompozytów polimerowo-cementowych obejmuje hydratację cementu i powstawanie ciągłej błony polimerowej. Model tworzenia się mikrostruktury kompozytu polimerowo-cementowego został opracowany i powszechne zaakceptowany $\mathrm{w}$ odniesieniu do betonów zawierających polimery termoplastyczne, chemicznie nieaktywne w mieszance betonowej (modyfikator typu pre-mix), takie jak poliestry akrylowe (PAE) itp. W tym przypadku błona polimerowa powstaje przez koalescencję cząstek polimeru. Jeśli natomiast stosuje się modyfikator typu post-mix (z reguły żywica epoksydowa), to dodatkowo zachodzi reakcja chemiczna między żywicą a utwardzaczem, prowadząca do przestrzennego usieciowania polimeru. W niniejszym artykule zaproponowano model tworzenia się mikrostruktury kompozytu epoksydowo-cementowego.

Żywica epoksydowa, wymieszana z utwardzaczem, tworzy emulsję w wodzie zarobowej. Składniki cementu zaczynają reagować z wodą, a jednocześnie rozpoczyna się utwardzanie żywicy przez reakcję z utwardzaczem. Proces ten zachodzi wewnątrz mikrokropelek. Kiedy na skutek usuwania wody z układu zostaje osiągnięte wystarczające stężenie polimeru, żywica jest już w większości utwardzona i koalescencja jest mało prawdopodobna. W rezultacie, struktura utwardzonej żywicy epoksydowej jest niejednorodna; powstają oddzielne grudki utwardzonej żywicy w stwardniałym zaczynie. Zatem, przy względnie małej zawartości polimeru, żywica epoksydowa jest mniej efektywna niż poliester akrylowy; działanie modyfikatora epoksydowego polega głównie na udziale jego własnej wytrzymałości we właściwościach kompozytu. Kiedy zawartość żywicy wzrasta, modyfikator epoksydowy staje się skuteczniejszy niż PAE (rys. 1, po lewej); prawdopodobieństwo koalescencji wzrasta, ponieważ wystarczające stężenie polimeru jest osiągane wcześniej. W ten sposób może powstawać bardziej jednorodna i ciągła warstwa polimeru.
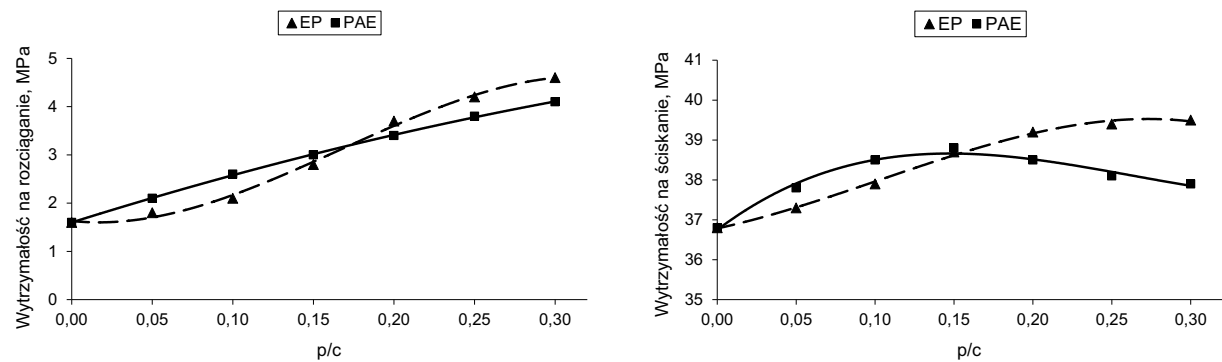

Rys. 1. Wytrzymałość na rozciąganie (po lewej) i ściskanie (po prawej) zapraw polimerowo-cementowych zawierających EP i PAE 
Interesujące wnioski można wyciągnąć na podstawie analizy wyników badań kompozytu modyfikowanego żywica epoksydową bez utwardzacza (rys. 2, po lewej). Sieciowanie żywicy na skutek katalitycznego działania środowiska przebiega znacznie wolniej niż w przypadku obecności utwardzacza. Utwardzanie żywicy zostaje więc opóźnione i prawdopodobieństwo koalescencji wzrasta. W takich warunkach może się tworzyć bardziej jednorodna, ciągła błona polimerowa (rys. 2, po prawej) a końcowa wytrzymałość kompozytu jest większa niż w przypadku zastosowania żywicy z utwardzaczem. Mechanizm kształtowania się mikrostruktury jest zatem, w takim przypadku, bardziej zbliżony do mechanizmu przyjętego dla polimerów termoplastycznych. Jednakże, kiedy zawartość polimeru wzrasta, nadmiar nieutwardzonej żywicy pogarsza właściwości kompozytu. W takiej sytuacji wytrzymałość tworzywa modyfikowanego żywicą z utwardzaczem staje się większa niż w przypadku żywicy bez utwardzacza.
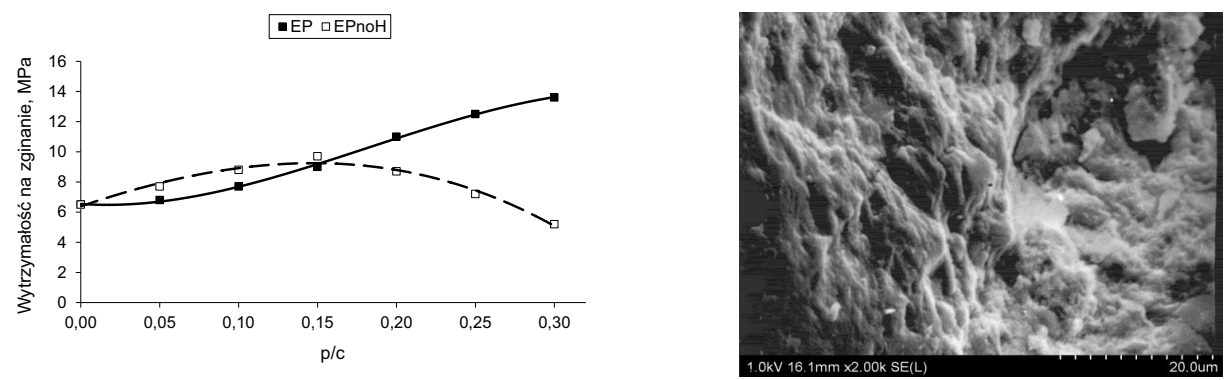

Rys. 2. Wytrzymałość na zginanie zapraw epoksydowo-cementowych - żywica epoksydowa stosowana z utwardzaczem (EP) i bez utwardzacza (EPnoH) (po lewej), oraz obraz mikroskopowy mikrostruktury kompozytu modyfikowanego żywicą epoksydową bez utwardzacza przy p/c $=0,15$ (po prawej)

Wiarygodny model tworzenia się mikrostruktury jest jednym z kluczowych elementów zrozumienia natury kompozytu i jego prawidłowego stosowania. Taki zintegrowany model został opracowany i zaakceptowany w odniesieniu do kompozytów polimerowo-cementowych zawierających polimery termoplastyczne. Natomiast proces kształtowania się mikrostruktury kompozytów epoksydowo-cementowych nie został, jak dotąd, w pełni wyjaśniony. W niniejszym artykule przedyskutowano odpowiedni mechanizm i zaproponowano wyjaśnienie obserwowanych zjawisk. Przedstawiony model został opracowany w oparciu o wyniki badań cech mechanicznych i obserwacji mikroskopowych kompozytów epoksydowo-cementowych; dalsze badania są niezbędne w celu weryfikacji modelu. 